DOI https://doi.org/10.30525/978-9934-26-074-2-26

\title{
ОХОРОНА ПРАЦІ ЯК СОЦІАЛЬНИЙ ФЕНОМЕН І КОМПЛЕКСНИЙ МІЖДИСЦИПЛІНАРНИЙ ІНСТИТУТ
}

\author{
Древаль Ю. Д. \\ доктор наук з державного управління, професор,
} професор кафедри охорони праці та техногенно-екологічної безпеки Національного університету циивільного захисту Украйни

\section{Бригада О. В.}

кандидат технічних наук, доиент, доцент кафедри охорони прачі та техногенно-екологічної безпеки Національного університету ичивільного захисту України

\section{Малько О. Д.}

кандидат військових наук, дочент, доцент кафедри охорони прачі та техногенно-екологічної безпеки Національного університету иивільного захисту Украйни м. Харків, Україна

Під інститутом традиційно розуміються правила, механізми, що забезпечують їх виконання, і норми поведінки, які структурують повторювані взаємодії між людьми. Правовим інститутом є сукупність норм права, засобом яких регулюється певний вид (сторона) однорідних суспільних відносин. Соціальний інститут у загальному вигляді розглядається як сталий комплекс формальних і неформальних правил, принципів, норм, установок, які регулюють різні сфери людської діяльності і організовують їх в систему ролей, статусів, що й утворює соціальну цілісність.

Інституалізація будь-якої сфери суспільних відносин відзначається низкою позитивних якостей. Вона, зокрема, дозволяє чітко окреслювати сутність заданої теми чи проблеми, регулювати поведінку різних соціальних груп та всього суспільства, створювати можливості задоволення різнобічних запитів та потреб, в кінцевому рахунку забезпечувати стабільність суспільного життя та створювати підгрунтя для його ефективного розвитку. Це повною мірою стосується й інституту охорони праці, яким охоплюється широкий спектр соціально-трудових та соціокультурних відносин. 
Сучасні дослідники характеризують інститут охорони праці в якості складної категорії, спрямованої на регулювання та вдосконалення соціально-трудових відносин. Природно, що найбільше уваги зазначеному інституту приділяють правознавці, першочергово представники трудового права.

Ще з радянських часів і до сьогодення інколи висловлюються й думки, що охорона праці є міждисциплінарним правовим інститутом, який слід розглядати в руслі багатьох галузей права. Наприклад, в 1970-ті рр. дослідники 3 проблем трудового права вказували на комплексний характер охорони праці, відзначаючи, що цей інститут охоплює низку норм та актів, які відносяться до багатьох суміжних галузей права (підкреслюючи ту обставину, що до законодавства у сфері охорони праці можуть бути віднесені норми державного, адміністративного, колгоспного, фінансового, цивільного та власне трудового права) [1, с. 70-71]. На думку сучасної дослідниці А. Нєвєрової, «характеризуючи інститут галузі, необхідно розглядати його структуру, яка $є$ не простою сукупністю правових норм, а диференційованою і водночас взаємопов'язаною асоціацією норм права» [2, с. 256].

Проте, на що слід звернути особливу увагу, наведені тлумачення не надають необхідного комплексу аргументів для повноцінного розуміння саме комплексного характеру охорони праці і не охоплює усієї складності сучасних працеохоронних відносин. Дійсно, визнаючи комплексний характер інституту охорони праці, слід обов'язково вказати і на те, що працеохоронною політикою опікуються й представники інших наукових галузей.

Базовим для сучасного розуміння суті працеохоронної політики $\epsilon$ поняття «охорона праці». Відповідно до ст. 1 Закону України «Про охорону праці» «Охорона праці - це система правових, соціально-економічних, організаційно-технічних, санітарно-гігієнічних і лікувальнопрофілактичних заходів та засобів, спрямованих на збереження життя, здоров’я і працездатності людини у процесі трудової діяльності». Відтак будь-яке обмеження системи охорони праці лише одним або однимдвома заходів та способів має вважатися не лише ненауковим, але i неправовим.

Методологічне значення у цьому відношенні має належати трактуванню поняття «охорона праці» у широкому та вузькому контекстах. Наприклад, С. Прилипко та О. Ярошенко широким значенням охоплюють визначення, яке наведене у ст. 1 Закону України «Про охорону праці» і при цьому стверджують: «Якщо будь-який з іiі складників (правовий, соціальний, медичний, організаційний тощо) не виконується (або неналежним чином виконується), то в цілому не забезпечується i охорона праці, що в кінцевому рахунку порушує 
конституційні права людини». У вузькому ж чи юридичному тлумаченні, за оцінкою дослідників, зазначений термін означає конкретний правовий інститут трудового права, який об’єднує норми, безпосередньо спрямовані на певне забезпечення умов праці, які є безпечними для життя і здоров'я працівників [3, с. 655].

Слід взяти до відома і позицію, якої притримуються деякі науковці, вживаючи категорію «надшироке розуміння охорони праці». Наприклад, як стверджує У. Бек, у надширокому розумінні охорону праці формують норми, що належать до різних галузей вітчизняного права і виходять за меді трудового права, але за своїм призначенням спрямовані на забезпечення безпечних і здорових умов праці, та нагляд i контроль у цій сфері [4, с. 3].

За нашою ж оцінкою, пошуки істини у даному питанні мають вестися якраз на стикові багатьох наукових галузей, що і зумовлюється застосуванням міждисциплінарних підходів. При цьому слід звернути особливу увагу на те, що у філософській і юридичній літературі серед властивостей права на перше місце здебільшого відносять саме по собі властивість нормативності, яка в позитивному праві набуває якості загальнообов'язкової нормативності [5, с. 49].

Проте, зміст інституту охорони праці має визначатися не лише за критеріями галузевої належності тих чи інших норм щодо забезпечення безпечних та нешкідливих умов праці, але i за деякими іншими критеріями. Дійсно, охорона праці є складним соціокультурним явищем, яке потребує не лише правових, але і багатьох інших соціальних регуляторів. Власне й належний стан охорони праці залежить від гармонійного поєднання правового регулювання та усвідомленого ставлення зацікавлених осіб до практичного забезпечення відповідних правил та стандартів.

\section{Література:}

1. Голощапов С.А. Охрана труда в СССР как комплексное законодательство. Советское государство и право. 1982. № 7. С. 67-74.

2. Нєвєрова А. Поняття і структура інституту охорони праці // Вісн. Львівського ун-ту. Серія юридична. 2013. Вип. 58. С. 255-260.

3. Прилипко С.М., Ярошенко О.М. Трудове право України: Підручник. 5-те вид., перероб. і доп. Харків: Вид-во «ФІНН», 2012. 800 с.

4. Бек У.П. Правове регулювання охорони праці в Україні: теоретичний аспект: автореферат дис... канд. юрид. наук: 12.00.05. Київ, 2013. 16 с.

5. Алексеев С.С. Восхождение к праву. Поиски и решения. М.: Издательство НОРМА, 2001. 752 с. 